\title{
Prediction of the Strength Properties of Carbon Fiber-Reinforced Lightweight Concrete Exposed to the High Temperature Using Artificial Neural Network and Support Vector Machine
}

\author{
Harun Tanyildizi \\ Department of Civil Engineering, Technology Faculty, Firat University, Elaziğ, Turkey \\ Correspondence should be addressed to Harun Tanyildizi; htanyildizi@firat.edu.tr
}

Received 24 August 2017; Accepted 9 November 2017; Published 31 January 2018

Academic Editor: Cumaraswamy Vipulanandan

Copyright (c) 2018 Harun Tanyildizi. This is an open access article distributed under the Creative Commons Attribution License, which permits unrestricted use, distribution, and reproduction in any medium, provided the original work is properly cited.

\begin{abstract}
The artificial neural network and support vector machine were used to estimate the compressive strength and flexural strength of carbon fiber-reinforced lightweight concrete with the silica fume exposed to the high temperature. Cement was replaced with three percentages of silica fumes $(0 \%, 10 \%$, and $20 \%)$. The carbon fibers were used in four different proportions $(0,2,4$, and $\left.8 \mathrm{~kg} / \mathrm{m}^{3}\right)$. The specimens of each concrete mixture were heated at $20^{\circ} \mathrm{C}, 400^{\circ} \mathrm{C}, 600^{\circ} \mathrm{C}$, and $800^{\circ} \mathrm{C}$. After this process, the specimens were subjected to the strength tests. The amount of cement, the amount of silica fumes, the amount of carbon fiber, the amount of aggregates, and temperature were selected as the input variables for the prediction models. The compressive and flexural strengths of the lightweight concrete were determined as the output variables. The model results were compared with the experimental results. The best results were achieved from the artificial neural network model. The accuracy of the artificial neural network model was found at $99.02 \%$ and $96.80 \%$.
\end{abstract}

\section{Introduction}

Many researchers have investigated lightweight concrete since the 1990s. The new requirements of concrete have contributed to development of lightweight concrete [1]. Lightweight aggregates have been classified as natural and artificial. Lightweight concrete can be made with higher strength, better tensile strength, and lower thermal expansion by using lightweight aggregate [2-4]. The fire resistance of concrete is complicated. Concrete has different thermal characteristics [5]. Researchers indicate that the addition of silica fume has caused high densities in the pore structure of concrete. It can result in big spalling because of the big pore pressure by steam when exposed at the elevated temperature [6]. Since the evaporation of water starts at $80^{\circ} \mathrm{C}$ in concrete, concretes with silica fume may show low performance when compared to concretes without silica fume at high temperatures [7]. Lightweight aggregates have high resistance to fire. The heat capacity of lightweight concrete is less than that of heavier concretes [8].
Fiber composites are new materials based on carbon fiber, steel fiber, and polymer fiber. Cement composite containing carbon fiber is used as the functional materials as well as the structural materials [9]. The carbon fiberreinforced concrete decreases the drying shrinkage and increases the flexural toughness $[10,11]$. The carbon fiber increases the flexural strength of concrete because it increases the ability to sense its own strain, damage, and temperature [12]. The loading capacity is increased when the steel fiber is used as an additive to the lightweight concretes. Furthermore, it has been decreasing the crack width of concrete $[13,14]$. Due to the advantageous properties, fiber composites have been used in concrete structures [9-19].

Researchers have recently studied the ANN modeling for concrete properties [20-27]. Zarandi et al. reported that a fuzzy polynomial neural network's model had been devised for prediction of the compressive strength of concrete [20]. Topcu and Saridemir showed that the ANN could be a predicted model with a tiny error [21-23]. Yeh indicated that the ANN was much more accurate than the regression analysis [24]. Demir showed that ANNs have the strong 
potential for predicting elastic modulus of the concrete [25]. Altun et al. concluded that the ANN predicts the compressive strength of lightweight concrete with steel fiber better than the multilinear regression technique [26]. İnan et al. reported that the neuro-fuzzy model exhibits superior performance [27].

The support vector machine (SVM) has been intensively applied to solve classification and function-approximation problems [28]. The SVMs use training and testing of data instances. While the neural network aims to minimize the errors, the SVMs seek to minimize the generalization error [29]. SVMs have been recently applied in civil engineering. Lee et al. successfully estimated the concrete strength using the SVR algorithm [30]. Chen et al. predicted the exposed temperature for concrete exposed to fire with SVM. They reported that the correctness of the model increased by the increase of the parameters [31]. Shi and Dong used to predict the strength of cement using SVM. They reported that SVM had become a practical method for the estimation of cement strength [32].

An ANN or SVM model for strength properties (compressive strength and flexural strength) of lightweight concrete with silica fume and carbon fiber after elevated temperature has not been investigated. Because of this, the models have been devised to predict the strength properties of lightweight concrete with silica fume and carbon fiber exposed to elevated temperature.

\section{Experimental Investigation}

2.1. Materials. The cement was selected as ordinary Portland cement (CEM I 42.5). Silica fume was provided from Turkey. The chemical analyses of these materials are shown in Table 1. The lightweight aggregate was selected for the concrete mixes. The specific gravity of lightweight aggregate was found to be 2 . The maximum grain size of lightweight aggregate was found to be $16 \mathrm{~mm}$. The water absorption of lightweight aggregate became $23 \%$. The properties of carbon fiber are presented in Table 2.

2.2. Specimens and Curing. The mix proportions are shown in Table 3. The superplasticizer was used in mixtures. The mixtures with silica fume and carbon fiber were prepared. The silica fume rates were used as $0 \%, 10 \%$, and $20 \%$. Furthermore, the carbon-fiber ratios were used as $0,2,4$, and $8 \mathrm{~kg} / \mathrm{m}^{3} .100 \mathrm{~mm}$ cubes were produced for the compressive strength. $100 \times 100 \times 500 \mathrm{~mm}$ prisms were produced for the flexural strength. Three specimens were produced for each temperature.

The specimens were kept in laboratory at $21 \pm 2^{\circ} \mathrm{C}$ for $24 \mathrm{~h}$. Then, the specimens were kept in a water tank for curing up to 28 days. After curing, they were exposed to $400^{\circ} \mathrm{C}, 600^{\circ} \mathrm{C}$, and $800^{\circ} \mathrm{C}$. They were kept for $1 \mathrm{~h}$ for each temperature [33]. The heating rate was $2.5^{\circ} \mathrm{C} /$ minute $[34,35]$. The specimens were allowed to cool naturally for one day.

\section{Experimental Results}

When the concrete is faced with high temperatures, the same effects may be occurring. The evaporable water passes
TABle 1: The chemical properties of cement and silica fume.

\begin{tabular}{lcc}
\hline \multirow{2}{*}{ Bulk oxide } & \multicolumn{2}{c}{ \% by mass } \\
& Portland cement & Silica fume \\
\hline $\mathrm{SiO}_{2}$ & 21.12 & 91 \\
$\mathrm{Al}_{2} \mathrm{O}_{3}$ & 5.62 & 0.58 \\
$\mathrm{Fe}_{2} \mathrm{O}_{3}$ & 3.24 & 0.24 \\
$\mathrm{CaO}$ & 62.94 & 0.71 \\
$\mathrm{MgO}$ & 2.73 & 0.33 \\
$\mathrm{LOI}$ & 1.42 & 1.84 \\
Specific surface area $\left(\mathrm{cm}^{2} / \mathrm{g}\right)$ & 3430 & - \\
Particle size & - & $96.5<45 \mu \mathrm{m}$ \\
Specific gravity $\left(\mathrm{g} / \mathrm{cm}^{3}\right)$ & 3.10 & 2.2 \\
\hline
\end{tabular}

Portland cement is ASTM Type I. Silica fume is mineral admixtures.

outwardly at $100^{\circ} \mathrm{C}$. The dehydration of the hydrate calcium silicate begins at $180^{\circ} \mathrm{C}$. The decomposition of calcium hydroxide occurs at $500^{\circ} \mathrm{C}$. More changes occur when the temperature is more than $500^{\circ} \mathrm{C}$ [36]. The decomposition of the hydrate calcium silicate begins around $700^{\circ} \mathrm{C}$. The changes of strength properties of concrete at the elevated temperatures are related to the concrete properties beside environmental factors [37].

The high-temperature damage on lightweight concrete with silica fume and carbon fiber was investigated. After the concrete specimens were exposed to $400^{\circ} \mathrm{C}, 600^{\circ} \mathrm{C}$, and $800^{\circ} \mathrm{C}$, the compressive and flexural strength tests were performed. The strength test results of specimens are given in Figures 1-6. As seen in Figures 1 and 4, compressive and flexural strengths of lightweight concretes without silica fumes showed slightly better performance, when the carbon-fiber percentage is 0.5 . When silica fume percentage was increased, the compressive and flexural strengths of lightweight concretes produced with $1 \%$ carbon fiber showed a better performance. Furthermore, the compressive and flexural strengths of lightweight concretes containing $2 \%$ carbon fiber were decreased in all temperatures. It can be seen from Figures 1-6 that the compressive and flexural strengths of carbon fiber-reinforced lightweight concrete decreased at $400^{\circ} \mathrm{C}$. The experimental results showed that, for each temperature, a strength loss was caused. These losses have been prevented with silica fume and carbon-fiber content. These losses can be become due to the escape of free water, and the hydration water on concrete after exposed to the high temperatures. The dehydration decreases the strength, elastic modulus, and thermal conductivity of concrete [38]. The concrete cracks are increased at high temperatures. The $\mathrm{C}-\mathrm{S}-\mathrm{H}$ crystals grow. They keep less space in the matrix at high temperatures. The high thermal stresses cause cracks. Therefore, the concrete microstructures are negatively affected because of these factors [39]. Since the high elastic modulus fibers restrict cracking inside the concrete, they can decrease the volume change of concrete. It has decreased the initiation and expansion of inner micro defects of concrete [40]. Çavdar investigated the effect of types of fibers on the flexural strength of cementitious composites exposed to high temperature [41]. The carbon fiber was not losing its properties, but the other fibers were deteriorated at high temperatures. Tanyildizi reported that carbon fibers 
TABLe 2: The properties of carbon fiber.

\begin{tabular}{ccccccc}
\hline Color & $\begin{array}{c}\text { Base } \\
\text { material }\end{array}$ & $\begin{array}{c}\text { Fiber } \\
\text { length } \\
(\mathrm{mm})\end{array}$ & $\begin{array}{c}\text { Compressive } \\
\text { strength }(7 \text { days }) \\
23^{\circ} \mathrm{C}\left(\mathrm{N} / \mathrm{mm}^{2}\right)\end{array}$ & $\begin{array}{c}\text { Bending } \\
\text { strength }(7 \text { days }) \\
23^{\circ} \mathrm{C}\left(\mathrm{N} / \mathrm{mm}^{2}\right)\end{array}$ & $\begin{array}{c}\text { Adhesion on } \\
\text { the concrete } \\
\left(\mathrm{N} / \mathrm{mm}^{2}\right)\end{array}$ & $\begin{array}{c}\text { Adhesion } \\
\text { on steel } \\
\left(\mathrm{N} / \mathrm{mm}^{2}\right)\end{array}$ \\
$\begin{array}{c}\text { Tensile } \\
\text { strength } \\
\left(\mathrm{N} / \mathrm{mm}^{2}\right)\end{array}$ \\
\hline Gray & Epoxy resin & 5 & 60 & 30 & 3.5 & 20 \\
\hline
\end{tabular}

Fiber refers to carbon fiber.

TABLE 3: Mixture proportion of concretes.

\begin{tabular}{|c|c|c|c|c|c|c|}
\hline $\begin{array}{l}\text { Designation } \\
\text { of mixture }\end{array}$ & $\begin{array}{l}\text { Cement } \\
\left(\mathrm{kg} / \mathrm{m}^{3}\right)\end{array}$ & $\begin{array}{c}\text { Silica fume } \\
\left(\mathrm{kg} / \mathrm{m}^{3}\right)\end{array}$ & $\begin{array}{c}\text { Carbon fiber } \\
\left(\mathrm{kg} / \mathrm{m}^{3}\right)\end{array}$ & $\mathrm{W} / \mathrm{C}$ & $\begin{array}{c}\text { Pumice aggregates } \\
\left(\mathrm{kg} / \mathrm{m}^{3}\right)\end{array}$ & $\begin{array}{c}\text { Superplasticizer } \\
\left(\mathrm{kg} / \mathrm{m}^{3}\right)\end{array}$ \\
\hline H0T0 & 400 & - & - & 0.77 & 1038 & 4.8 \\
\hline H0.5T0 & 400 & - & 2 & 0.77 & 1038 & 4.8 \\
\hline H1T0 & 400 & - & 4 & 0.77 & 1038 & 4.8 \\
\hline H2T0 & 400 & - & 8 & 0.77 & 1038 & 4.8 \\
\hline H0T10 & 360 & 40 & - & 0.77 & 1028 & 4.8 \\
\hline $\mathrm{H} 0.5 \mathrm{~T} 10$ & 360 & 40 & 2 & 0.77 & 1028 & 4.8 \\
\hline H1T10 & 360 & 40 & 4 & 0.77 & 1028 & 4.8 \\
\hline $\mathrm{H} 2 \mathrm{~T} 10$ & 360 & 40 & 8 & 0.77 & 1028 & 4.8 \\
\hline H0T20 & 320 & 80 & - & 0.77 & 1015 & 4.8 \\
\hline H0.5T20 & 320 & 80 & 2 & 0.77 & 1015 & 4.8 \\
\hline $\mathrm{H} 1 \mathrm{~T} 20$ & 320 & 80 & 4 & 0.77 & 1015 & 4.8 \\
\hline $\mathrm{H} 2 \mathrm{~T} 20$ & 320 & 80 & 8 & 0.77 & 1015 & 4.8 \\
\hline
\end{tabular}

Cement is ASTM Type I.

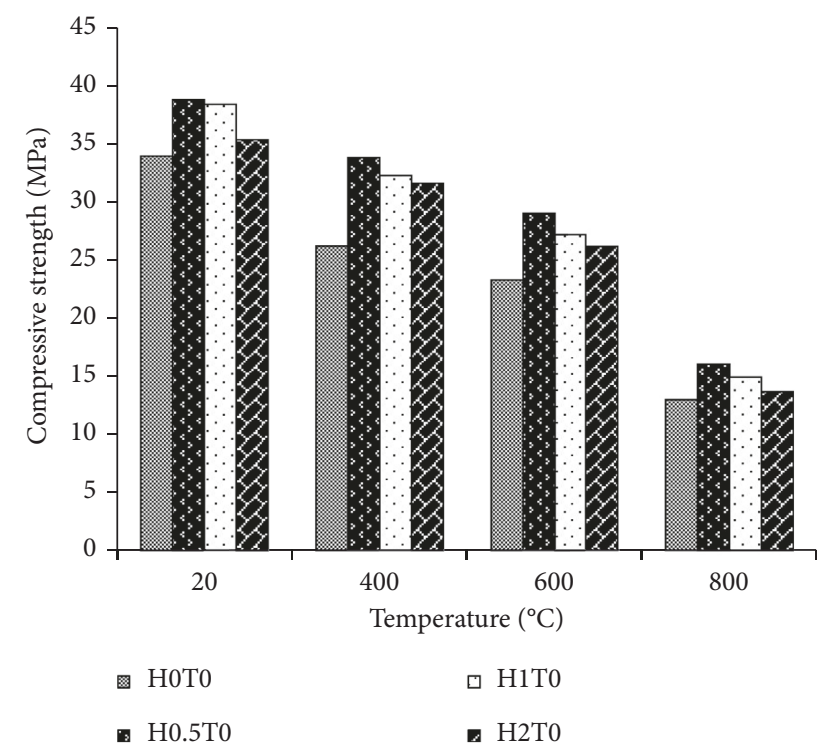

FIGURE 1: Compressive strength results for carbon fiber-reinforced lightweight concrete without silica fume.

could improve the high-temperature performance of the lightweight concrete [42].

\section{Prediction of Experimental Results}

4.1. Prediction Model Based on Artificial Neural Network. An artificial neural network (ANN) is based on the operations of biological neural networks. Therefore, ANN can be defined as

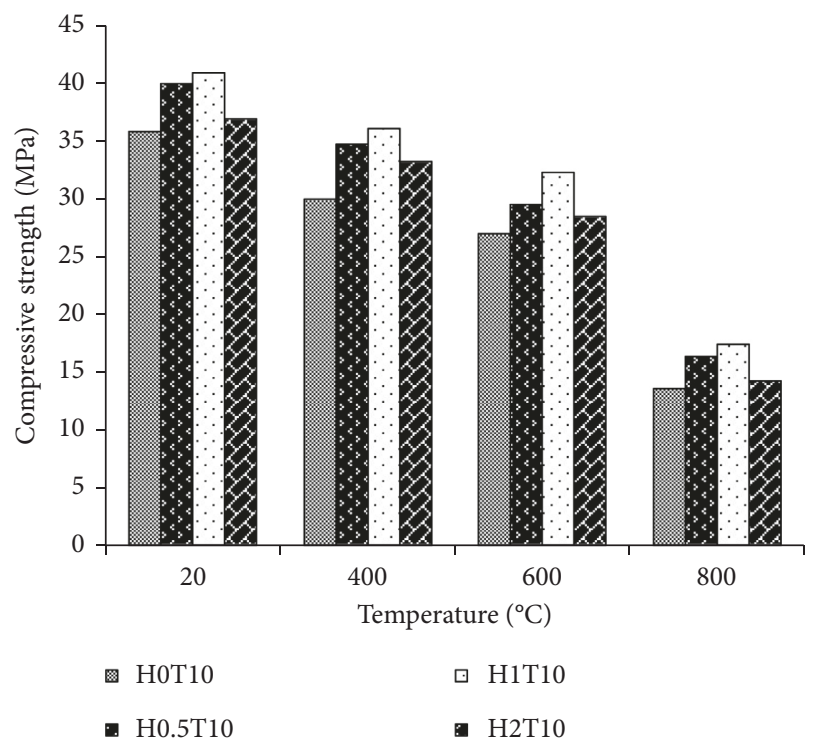

Figure 2: Compressive strength results for carbon fiber-reinforced lightweight concrete containing $10 \%$ silica fume.

an emulation of biological neural systems [43]. ANN has amazing capability in modeling the human brain [44]. ANN is the occurrence of a large number of simple processing elements called neurons. An artificial neuron model is shown in Figure 7.

$W_{j}$ is used as the weight for the input $X_{j}$. Bias is $b$. Let $X=$ $\left(X_{1}, X_{2}, \ldots, X_{n}\right)$ be symbolized the $n$ input to the neuron. Equation (1) is the output of the neuron. They depend on the connection links. There is a weight of each link. There is an activation function. This function is used to calculate the 


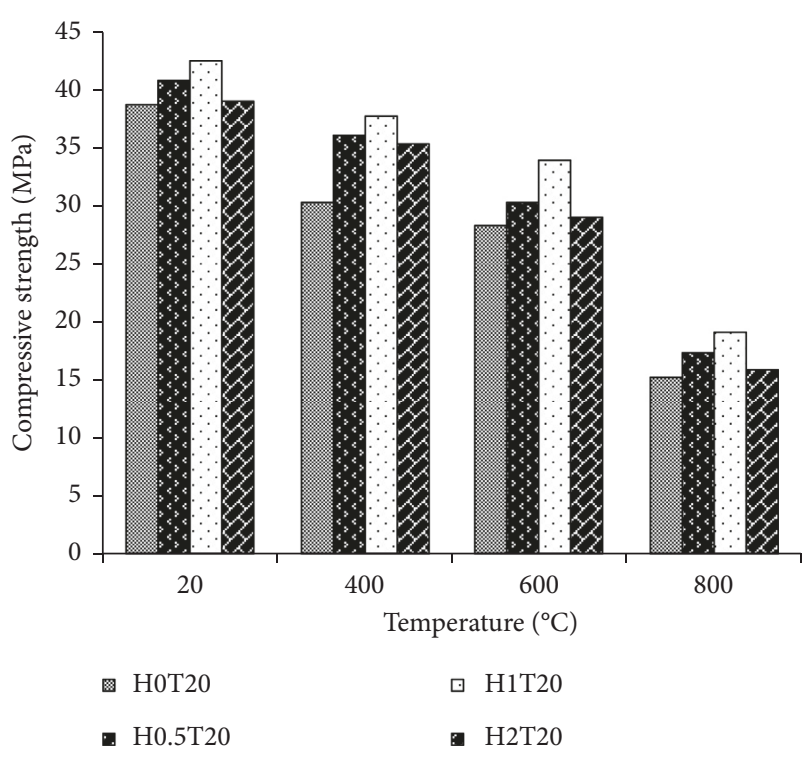

FIGURE 3: Compressive strength results for carbon fiber-reinforced lightweight concrete containing $20 \%$ silica fume.

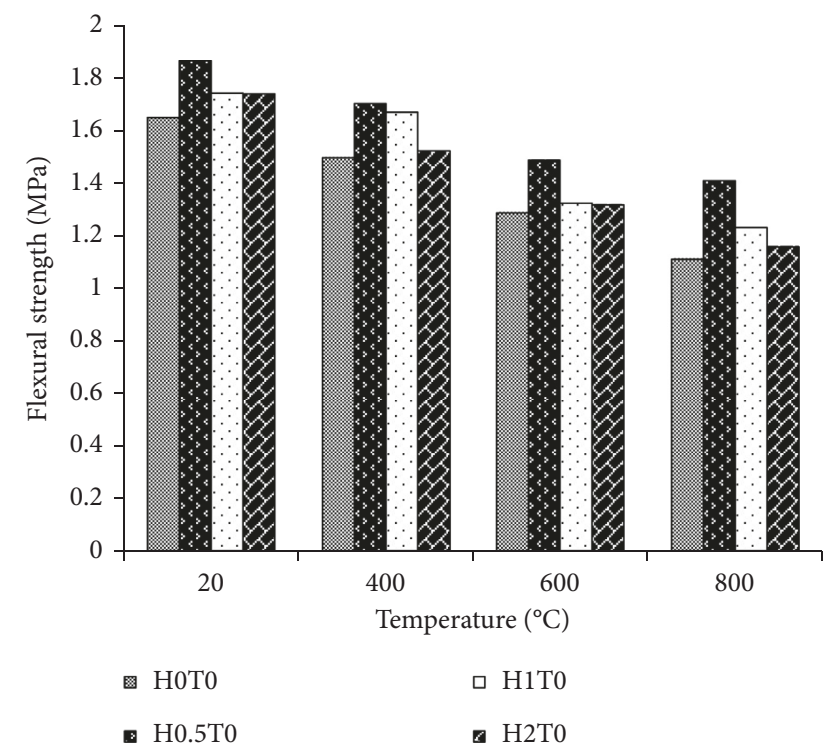

FIgURE 4: Flexural strength results for carbon fiber-reinforced lightweight concrete without silica fume.

output of each neuron. Many kinds of activation function can be used.

$$
\begin{aligned}
u & =\sum_{j=0}^{m} x_{j} w_{j}-b, \\
V & =f(u) .
\end{aligned}
$$

When an ANN model is devised, many factors must be considered. After this, the activation function and the most suitable structure for the ANN model must be established. Furthermore, the number of layers and the units in each layer must be detected [45-47]. Many kinds of ANN structure can be used. The multilayer feed-forward ANN is one of these. This structure is given in Figure 8.

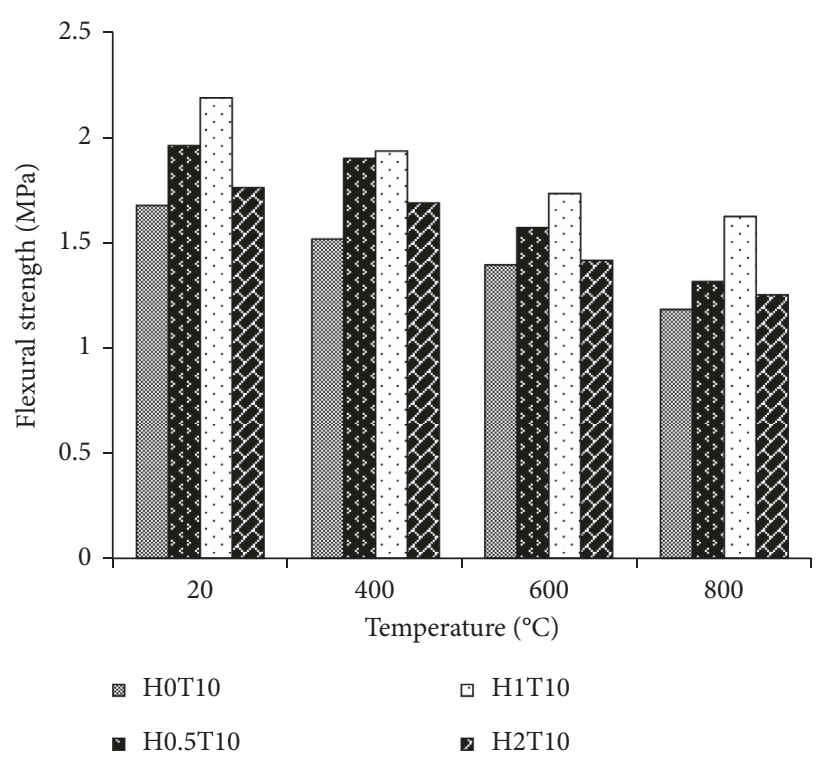

FIGURE 5: Flexural strength results for carbon fiber-reinforced lightweight concrete containing $10 \%$ silica fume.

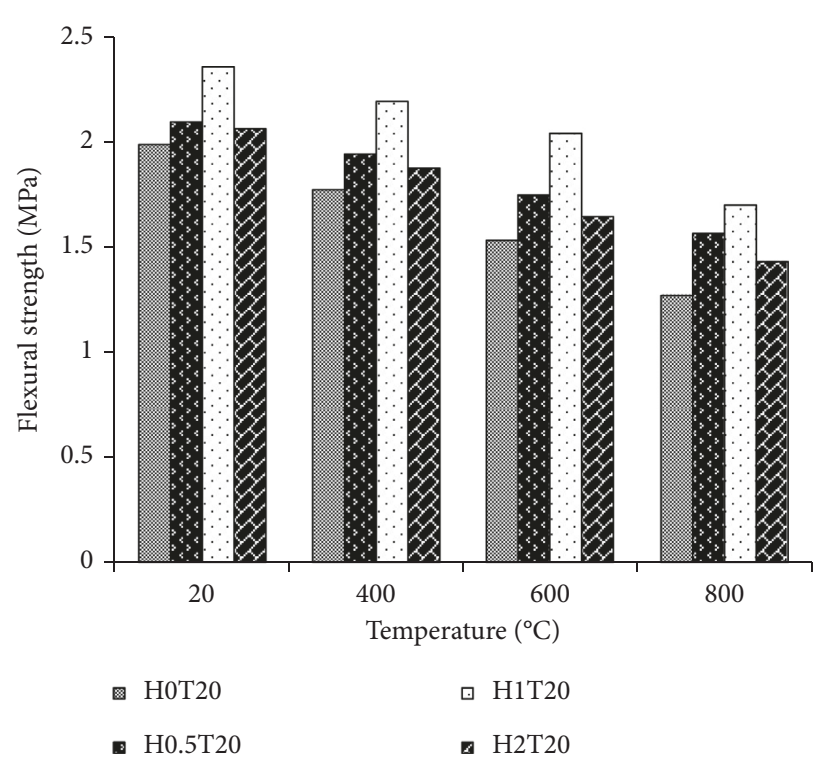

FIGURE 6: Flexural strength results for carbon fiber-reinforced lightweight concrete containing $20 \%$ silica fume.

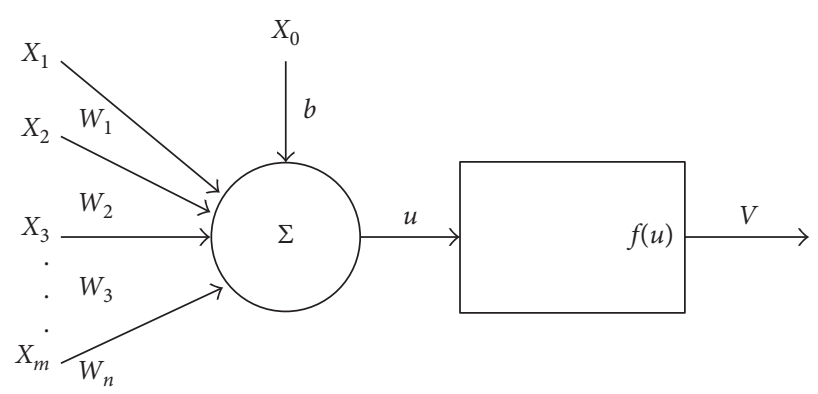

FIgURE 7: Artificial neuron model. $W_{j}$ represents the weight for input $X_{j}$, and $b$ is a bias. 


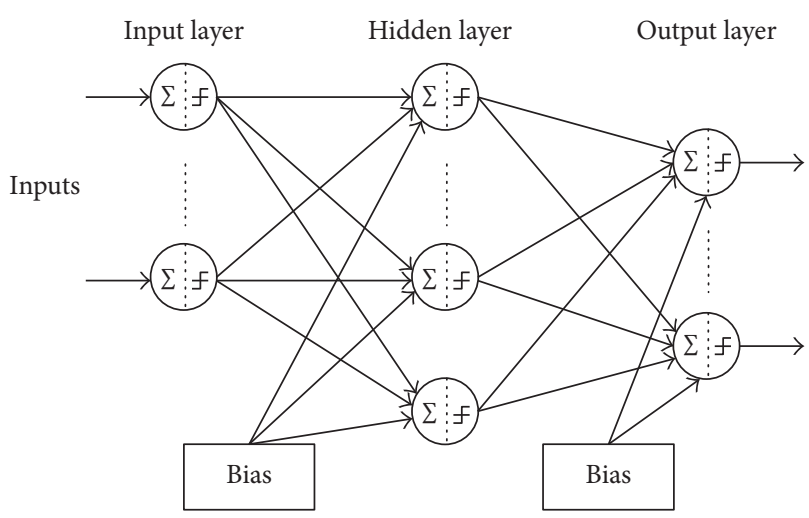

Figure 8: Multilayer feed-forward neural network structure.

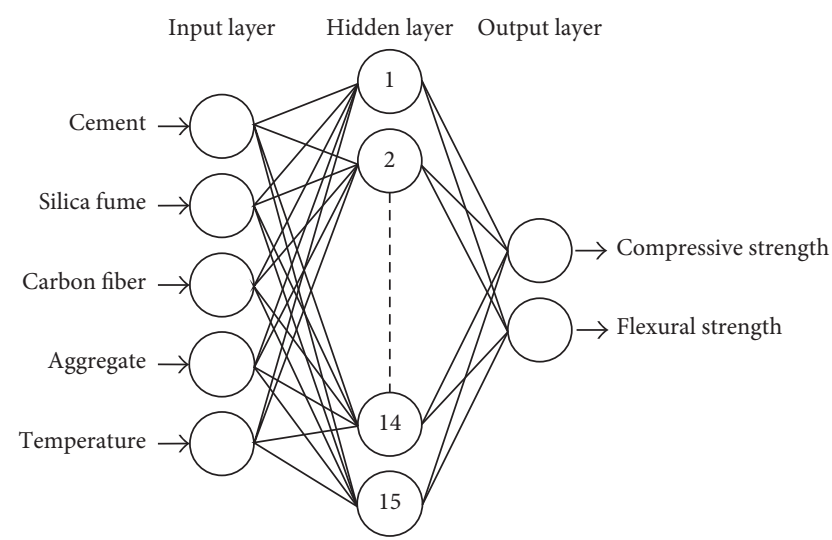

FIGURE 9: ANN architecture.

An artificial network model was designed with five input and two output parameters. The amount of cement, the amount of silica fumes, the amount of carbon fiber, and the amount of aggregates and temperature were selected as input variables. The compressive and flexural strengths of the carbon fiber-reinforced lightweight concrete were used as the model output variables. The back propagation learning algorithm was selected as a feed-forward algorithm for this study. Besides, it determined a single hidden layer neural network. The model is shown in Figure 9.

Three different algorithms are selected. The algorithms are the Levenberg-Marquardt (LM) backpropagation, Polak-Ribiere conjugate gradient projection (CGP) backpropagation, and one-step secant (OSS) backpropagation algorithms. The number of neurons in the layer is found to be fifteen. 144 experimental results have been obtained for artificial neural networks. They were divided by max values to normalize. From these data, 72 data were selected for the training. The other 72 data were randomly selected for the testing. The ANN results are given in Figures 10-18.

The measured and predicted strengths are shown in Figures 11, 12, 14, 15, 17, and 18. The training performance is given in Figures 10, 13, and 16. It can be seen from Figure 10, 13 and 16 that Levenberg-Marquardt, Polak-Ribiere conjugate gradient and One-step secant backpropagation algorithms have completely learned this study. It can be seen from Figures 11, 14, and 17 that the ANN models have

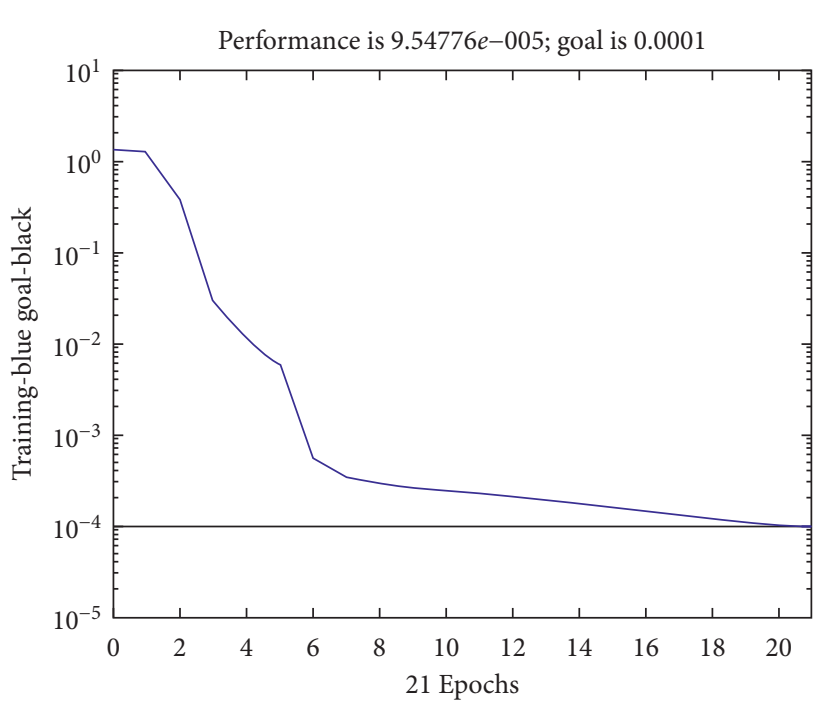

Figure 10: Training performance for the Levenberg-Marquardt backpropagation algorithm of ANN.

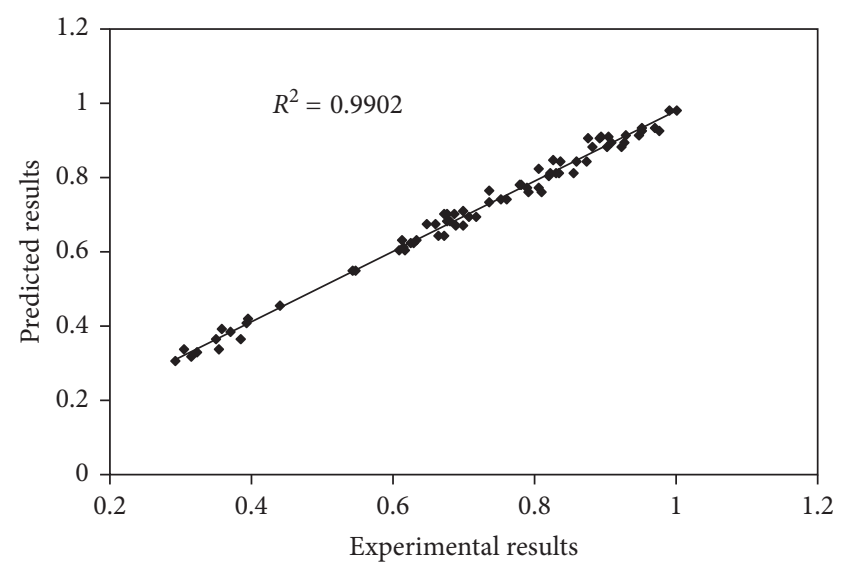

FIGURE 11: Linear relationship between measured and predicted compressive strengths for the Levenberg-Marquardt backpropagation algorithm of ANN.

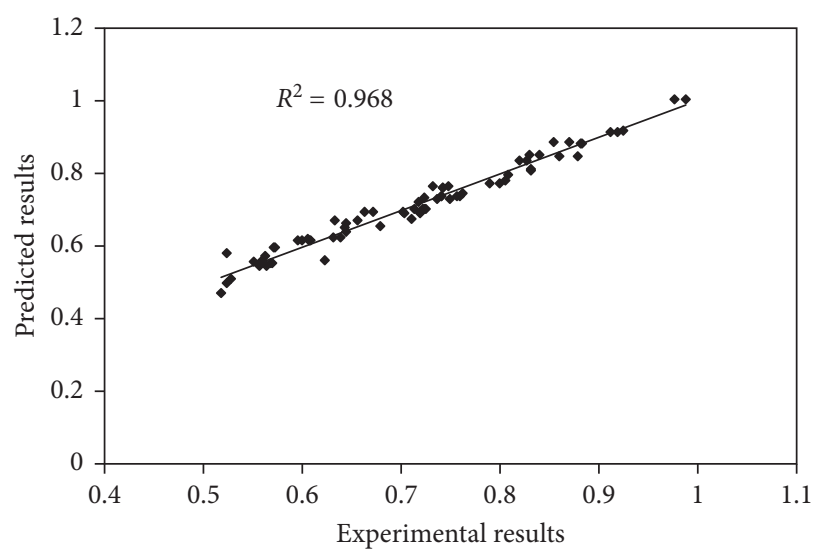

FIGURE 12: Linear relationship between measured and predicted flexural strengths for the Levenberg-Marquardt backpropagation algorithm of ANN. 


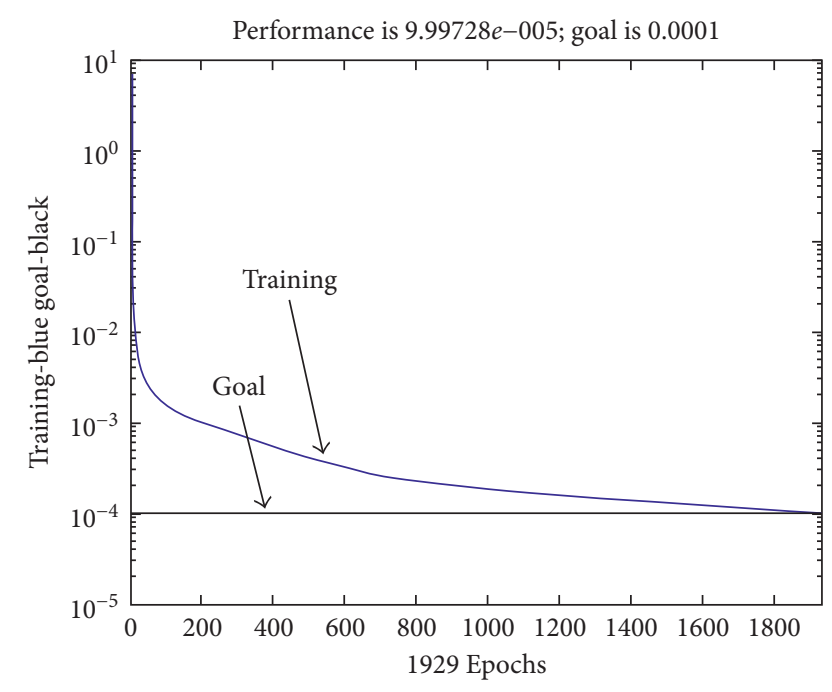

FIgURE 13: Training performance for the Polak-Ribiere conjugate gradient backpropagation algorithm of ANN.

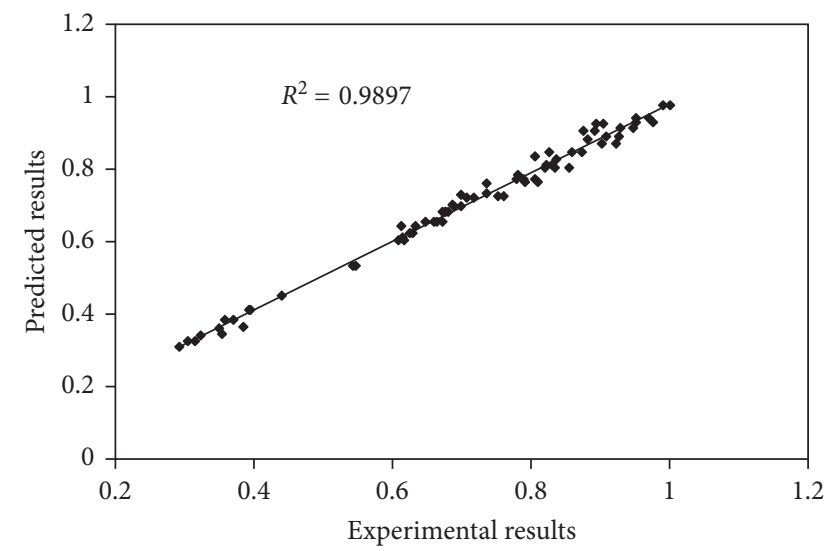

FIGURE 14: Linear relationship between measured and predicted compressive strengths for the Polak-Ribiere conjugate gradient backpropagation algorithm of ANN.

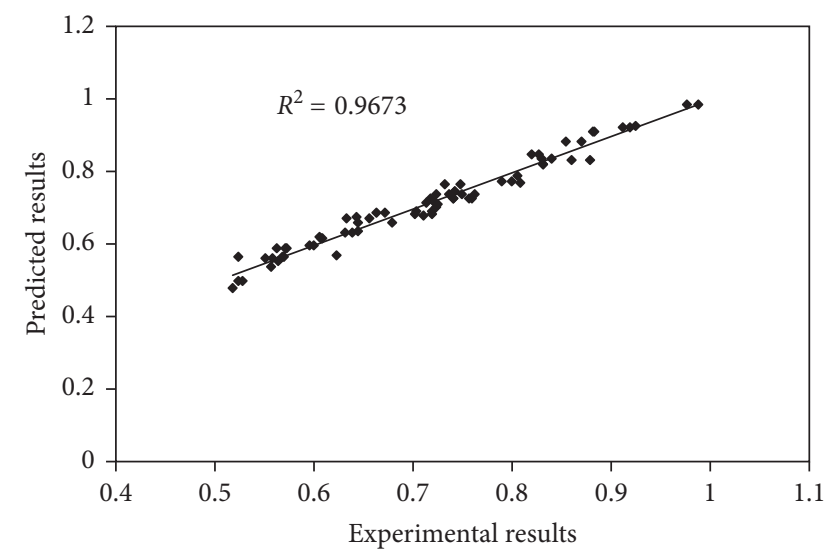

FIGURE 15: Linear relationship between measured and predicted flexural strengths for the Polak-Ribiere conjugate gradient backpropagation algorithm of ANN.

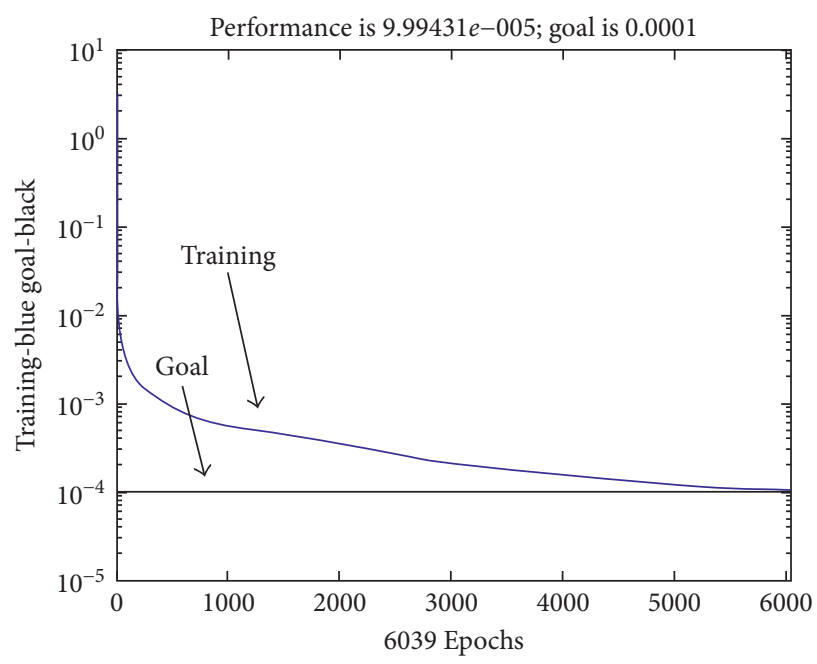

FIgURE 16: Training performance for the one-step secant backpropagation algorithm of ANN.

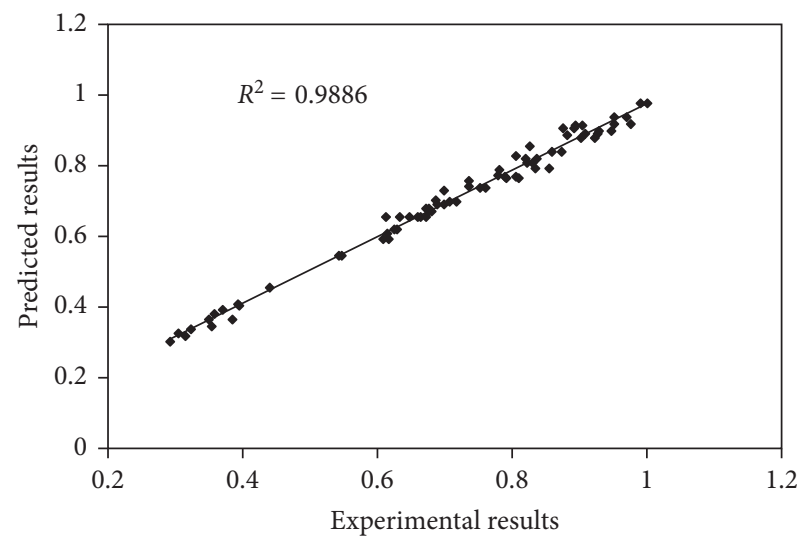

FIGURE 17: Linear relationship between measured and predicted compressive strengths for the one-step secant backpropagation algorithm of ANN.

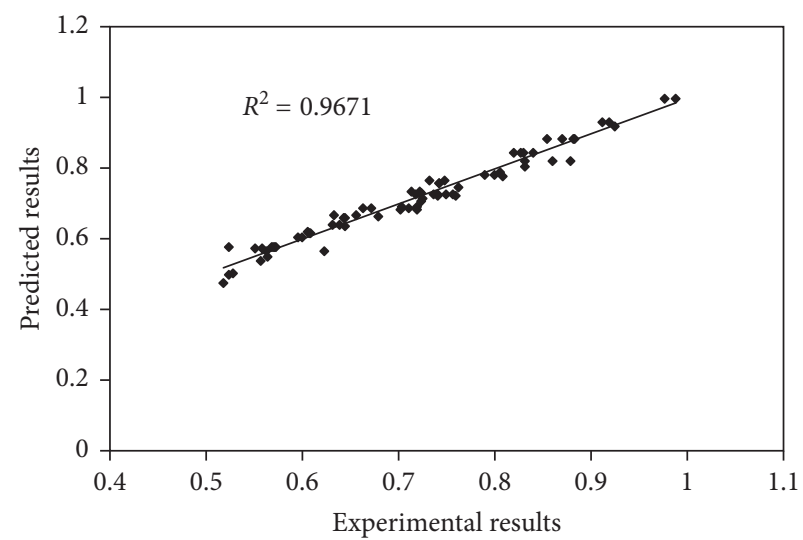

FIGURE 18: Linear relationship between measured and predicted flexural strengths for the one-step secant backpropagation algorithm of ANN. 
predicted the compressive strength of carbon fiber-reinforced lightweight concrete exposed to the high temperature with $R^{2}$ of $0.9902,0.9897$, and 0.9886 . However, Figures 12,15 , and 18 show that the ANN models have predicted the flexural strength of carbon fiber-reinforced lightweight concrete exposed to the high temperature with $R^{2}$ of $0.9680,0.9673$, and 0.9671 . The best learning algorithm for compressive and flexural strengths was Levenberg-Marquardt backpropagation because the maximum correlation coefficient $\left(R^{2}\right)$ was obtained from the Levenberg-Marquardt backpropagation. This algorithm was commonly applied [26]. This was also shown in other articles in the literature [48-54]. The artificial neural networks could be used to solve the complicated civil engineering problems [55].

\subsection{Prediction Model Based on Support Vector Machine} Model. Support vector machines (SVMs) are used to obtain good generalization. Support vector machines attempt to minimize the generalization error [56]. Support vector machines were introduced by Vapnik [57]. The SVM theory can be explained as follows: The binary classification problem with its training set of $N$ sample points is shown by

$\left(\left(x_{1}, y_{1}\right), \ldots,\left(x_{i}, y_{i}\right), \ldots,\left(x_{N}, y_{N}\right)\right), \quad x_{i} \in R^{d}, y_{i} \in\lfloor-1,1\rfloor$.

$x_{i}$ is a sample value of the input vector $x$ consisting of $N$ training patterns. $y_{i}$ is the corresponding value of the desired model output. $\hat{y}$ is represented as a linear function. The function is shown by

$$
\widehat{y}_{i}=f(x)=w^{T} \phi(x)+b .
$$

The coefficient is $w . w$ is a one-dimensional array. The superscript " $T$ " denotes transposed. $\phi(x)$ is a nonlinear transformation function. It is used to map the input space to a higher-dimension feature space. The SVM is used to minimize the empirical risk variable. $R_{\mathrm{emp}}$ is defined as

$$
R_{\mathrm{emp}}=\frac{1}{N} \sum_{i=1}^{N}\left|y_{i}-\widehat{y}_{i}\right|_{\varepsilon}
$$

$\left|y_{i}-\widehat{y}_{i}\right|_{\mathcal{E}}$ is Vapnik's $\mathcal{\varepsilon}$-insensitive loss function defined as

$$
\left|y_{i}-\widehat{y}_{i}\right|_{\varepsilon}=\left\{\begin{array}{l}
0 \text { if }\left|y_{i}-\widehat{y}_{i}\right| \leq \varepsilon \\
\left|y_{i}-\hat{y}_{i}\right|-\varepsilon \quad \text { otherwise. }
\end{array}\right.
$$

$w$ and $b$ are then estimated by minimizing the cost function $J_{\varepsilon}\left(w, \xi, \xi^{*}\right)$ defined by

$$
J\left(w, \xi, \xi_{i}^{*}\right)=\frac{1}{2} w^{T} w+C \sum_{i=1}^{N}\left(\xi+\xi_{i}^{*}\right) .
$$

The constraints are given as follows:

$$
\begin{array}{rl}
y_{i}-\hat{y}_{i} \leq \varepsilon+\xi_{i} & i=1,2, \ldots, N, \\
-y_{i}+\hat{y}_{i} \leq \varepsilon+\xi_{i}^{*} & i=1,2, \ldots, N,
\end{array}
$$

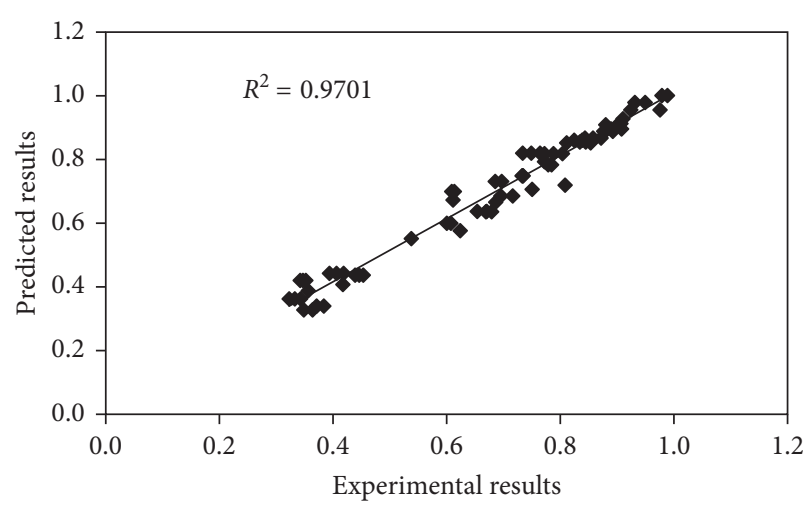

FIGURE 19: Linear relationship between measured and predicted compressive strengths of support vector machine model.

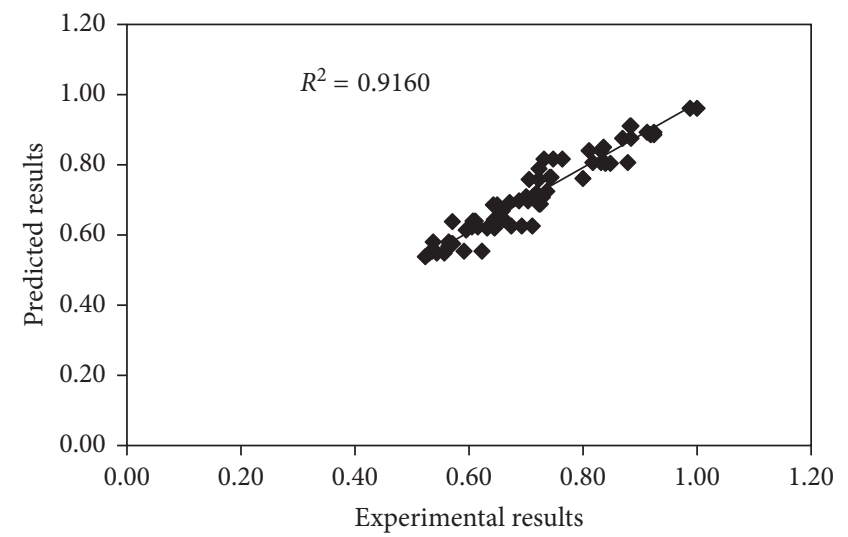

FIGURE 20: Linear relationship between measured and predicted flexural strengths of support vector machine model.

$$
\begin{aligned}
& \xi_{i} \geq 0 \quad i=1,2, \ldots, N \\
& \xi_{i}^{*} \geq 0 \quad i=1,2, \ldots, N
\end{aligned}
$$

$\xi_{i}$ and $\xi_{i}^{*}$ are positive slack variables. $C$ is a positive real constant [31, 56-59].

In this study, a support vector model was designed by using five input and output parameters. The input variables were used as the amount of cement, the amount of silica fumes, the amount of carbon fiber, and the amount of aggregates and temperature. The model output variables were the compressive and flexural strengths of the carbon fiberreinforced lightweight concrete. Several parameters are needed to be known for the SVR algorithm. Firstly, it should be determined by three parameters. The parameters are $C$, error insensitive zone $(\varepsilon)$, and kernel specific parameters $(\gamma)$ [56]. The optimal values of the parameters were obtained after several trials with these data. The optimal values of $C, \varepsilon$, and $\gamma$ were $100,1.1 \times 10^{-6}$, and 0.9 , respectively. Furthermore, data were divided by max values to normalize. 72 data were used for training. Besides, the other 72 data were randomly used as the test data set. The SVM results are given in Figures 19 and 20. 
It can be seen from Figures 19 and 20 that the support vector model has predicted the compressive and flexural strengths of carbon fiber-reinforced concrete exposed to the high temperature with an $R^{2}$ of 0.9701 and 0.91602 , respectively. Although the ANN model showed a good performance to estimate the compressive strength and flexural strength of carbon fiber-reinforced lightweight concrete exposed to the high temperature, it has a large number of controlling parameters. These parameters need to be optimum. This should be made an effort. The SVM model consists of three parameters [60]. It can be said that few parameters are easy to identify.

\section{Conclusions}

The prediction models (ANN and SVM) were devised for the strength properties of carbon fiber-reinforced concrete with the silica fume exposed to the high temperature. The $0 \%$, $10 \%$, and $20 \%$ silica fumes of cement were used in this study. Furthermore, the carbon-fiber volume was used 0, 0.5, 1 and $2 \%$ in concrete mixtures. After exposed to $20^{\circ} \mathrm{C}, 400^{\circ} \mathrm{C}$, $600^{\circ} \mathrm{C}$, and $800^{\circ} \mathrm{C}$, the compressive and flexural strength tests of lightweight concrete were performed. The high compressive and flexural strength results were obtained experimentally from the lightweight concrete with $20 \%$ silica fume and $1 \%$ carbon fiber for all temperatures. Furthermore, compressive and flexural strengths were decreased with $2 \%$ carbon fiber for all mixes and temperatures. SVM models predicted the compressive and flexural strengths with $R^{2}$ values of 0.9701 and 0.9160 , respectively. Three ANN algorithms were tested in this study. The best learning algorithm was obtained as Levenberg-Marquardt algorithm for this study. The ANN prediction model showed a very good statistical performance because the correlation coefficients $\left(R^{2}\right)$ between measured and predicted results for compressive and flexural strengths were 0.9902 and 0.9680 , respectively. Finally, the results showed that the artificial neural network prediction model could be used with a high degree of accuracy and reliability for the strength properties of lightweight concrete with silica fume and carbon fiber after exposed to high temperature.

\section{Conflicts of Interest}

The authors declare that they have no conflicts of interest.

\section{References}

[1] J. A. Bogas and A. Gomes, "Compressive behavior and failure modes of structural lightweight aggregate concrete characterization and strength prediction," Materials \& Design, vol. 46, pp. 832-841, 2013.

[2] A. Kılıç, C. D. Atis, E. Yaşar, and F. Özcan, "High-strength lightweight concrete made with scoria aggregate containing mineral admixtures," Cement and Concrete Research, vol. 33, no. 10, pp. 1595-1599, 2003.

[3] I. B. Topcu, "Semi-lightweight concretes produced by volcanic slags," Cement and Concrete Research, vol. 27, no. 1, pp. 15-21, 1997.
[4] H. Al-Khaiat and M. N. Haquet, "Effect of initial curing on early strength and physical properties of lightweight concrete," Cement and Concrete Research, vol. 28, no. 6, pp. 859-866, 1998.

[5] S. P. Shah and S. H. Ahmad, High Performance Concrete, Properties and Applications, p. 341, McGraw-Hill, New York, NY, USA, 1994.

[6] C. S. Poon, S. Azhar, M. Anson, and Y. L. Wong, "Performance of metakaolin concrete at elevated temperatures," Cement and Concrete Composites, vol. 25, no. 1, pp. 83-89, 2003.

[7] L. T. Phan, Fire Performance of High Strength Concrete, A Report of the State-of-the-Art, Building and Fire Research Laboratory, National Institute of Standards and Technology, Gaithersburg, MD, USA, 1996.

[8] M. M. Shoaib, S. A. Ahmed, and M. M. Balaha, "Effect of fire and cooling mode on the properties of slag mortars," Cement and Concrete Research, vol. 31, no. 11, pp. 1533-1538, 2001.

[9] W. Wang, S. Wu, and H. Dai, "Fatigue behavior and life prediction of carbon fiber reinforced concrete under cyclic flexural loading," Materials Science and Engineering A, vol. 434, no. 1-2, pp. 347-351, 2006.

[10] P. W. Chen, X. Fu, and D. D. L. Chung, "Microstructural and mechanical effects of latex, methylcellulose and silica fume on carbon fiber reinforced cement," ACI Materials Journal, vol. 94, no. 2, pp. 147-155, 1997.

[11] Y. Xu and D. D. L. Chung, "Improving silica fume cement by using silane," Cement Concrete Research, vol. 30, no. 8, pp. 1305-1311, 2000.

[12] S. Zu, Z. Li, X. Song, and D. D. L. Chung, "Deformation adjustment of concrete beams laminated with carbon fiber mats," Construction and Building Materials, vol. 21, no. 3, pp. 621-625, 2007.

[13] Y. Mohammadi, S. P. Singh, and S. K. Kaushik, "Properties of steel fibrous concrete containing mixed fibers in fresh and hardened states," Construction and Building Materials, vol. 22, no. 5, pp. 956-965, 2008.

[14] F. Altun and B. Aktaş, "Investigation of reinforced concrete beams behavior of steel fiber added lightweight concrete," Construction and Building Materials, vol. 38, pp. 575-581, 2013.

[15] M. Hassanpour, P. Shafigh, and H. B. Mahmud, "Lightweight aggregate concrete fiber reinforcement-a review," Construction and Building Materials, vol. 37, pp. 452-461, 2012.

[16] A. C. Aydin, "Self compactability of high volume hybrid fiber reinforced concrete," Construction and Building Materials, vol. 21, no. 6, pp. 1149-1154, 2007.

[17] U. S. Camli and B. Binici, "Strength of carbon fiber reinforced polymers bonded to concrete and masonry," Construction and Building Materials, vol. 21, no. 7, pp. 1431-1446, 2007.

[18] A. Cevik and I. H. Guzelbey, "Neural network modeling of strength enhancement for CFRP confined concrete cylinders," Building and Environment, vol. 43, no. 5, pp. 751-763, 2008.

[19] I. B. Topcu and M. Canbaz, "Effect of different fibers on the mechanical properties of concrete containing fly ash," Construction and Building Materials, vol. 21, no. 7, pp. 1486-1491, 2007.

[20] M. H. F. Zarandi, I. B. Türksen, J. Sobhani, and A. A. Ramezanianpour, "Fuzzy polynomial neural networks for approximation of the compressive strength of concrete," Applied Soft Computing, vol. 8, no. 1, pp. 488-498, 2008.

[21] I. B. Topcu and M. Saridemir, "Prediction of properties of waste AAC aggregate concrete using artificial neural 
network," Computational Materials Science, vol. 41, no. 1, pp. 117-125, 2007.

[22] I. B. Topcu and M. Sarıdemir, "Prediction of rubberized mortar properties using artificial neural network and fuzzy logic," Journal of Materials Processing Technology, vol. 199, no. 1-3, pp. 108-118, 2008.

[23] I. B. Topcu and M. Saridemir, "Prediction of mechanical properties of recycled aggregate concretes containing silica fume using artificial neural networks and fuzzy logic," Computational Materials Science, vol. 42, no. 1, pp. 74-82, 2008.

[24] I. C. Yeh, "Modeling slump flow of concrete using secondorder regressions and artificial neural networks," Cement and Concrete Composites, vol. 29, no. 6, pp. 474-480, 2007.

[25] F. Demir, "Prediction of elastic modulus of normal and high strength concrete by artificial neural networks," Construction and Building Materials, vol. 22, no. 7, pp. 1428-1435, 2008.

[26] F. Altun, O. Kişi, and K. Aydin, "Predicting the compressive strength of steel fiber added lightweight concrete using neural network," Computational Materials Science, vol. 42, no. 2, pp. 259-265, 2008.

[27] G. İnan, A. B. Göktepe, K. Ramyar, and A. Sezer, "Prediction of sulfate expansion of PC mortar using adaptive neuro-fuzzy methodology," Building and Environment, vol. 42, no. 3, pp. 1264-1269, 2007.

[28] V. Ranković, N. Grujović, D. Divac, and N. Milivojević, "Development of support vector regression identification model for prediction of dam structural behavior," Structural Safety, vol. 48, pp. 33-39, 2014.

[29] Y. R. Wang, C. Y. Yu, and H. H. Chan, "Predicting construction cost and schedule success using artificial neural networks ensemble and support vector machines classification models," International Journal of Project Management, vol. 30, no. 4, pp. 470-478, 2012.

[30] J. J. Lee, D. K. Kim, S. K. Chang, and J. H. Lee, “Application of support vector regression for the prediction of concrete strength," Computers Concrete, vol. 4, no. 4, pp. 299-316, 2007.

[31] B. T. Chen, T. P. Chang, J. Y. Shih, and J. J. Wang, "Estimation of exposed temperature for fire-damaged concrete using support vector machine," Computational Materials Science, vol. 44, no. 3, pp. 913-920, 2009.

[32] X. C. Shi and Y. F. Dong, "Support vector machine applied to prediction strength of cement," in Proceedings of the 2nd International Conference on Artificial Intelligence, Management Science and Electronic Commerce (AIMSEC), pp. 1585-1588, IEEE, Zhengzhou, China, August 2011.

[33] G. T. G. Mohamedbhai, "Effect of exposure time and rates of heating and cooling on residual strength of heated concrete," Magazine of Concrete Research, vol. 38, no. 136, pp. 151-158, 1986.

[34] Y. N. Chan, G. F. Peng, and M. Anson, "Residual strength and pore structure of high-strength concrete and normal-strength concrete after exposure to high temperatures," Cement and Concrete Composites, vol. 21, no. 1, pp. 23-27, 1999.

[35] K. M. A. Hossain, "High strength blended cement concrete incorporating volcanic ash: performance at high temperatures," Cement and Concrete Composites, vol. 28, no. 6, pp. 535-545, 2006.

[36] B. M. Luccioni, M. I. Figueroa, and R. F. Danesi, "Thermomechanic model for concrete exposed to elevated temperatures," Engineering Structures, vol. 25, no. 6, pp. 729-742, 2003.
[37] Y. N. Chan, X. Luo, and W. Sun, "Compressive strength and pore structure of high-performance concrete after exposure to high temperature up to $800^{\circ} \mathrm{C}$," Cement and Concrete Research, vol. 30, no. 2, pp. 247-251, 2000.

[38] K. Sakr and E. E. Hakim, "Effect of high temperature or fire on heavy weight concrete properties," Cement and Concrete Research, vol. 35, no. 3, pp. 590-596, 2005.

[39] T. R. Naik and R. N. Kraus, Temperature Effects on HighPerformance Concrete, Report no. CBU-2002-07 REP-460, Department of Civil Engineering and Mechanics, College of Engineering and Applied Science, University of WisconsinMilwaukee, Milwaukee, WI, USA, 2002.

[40] B. Chen and J. Liu, "Residual strength of hybrid-fiberreinforced high-strength concrete after exposure to high temperatures," Cement and Concrete Research, vol. 34, no. 6, pp. 1065-1069, 2004.

[41] A. Çavdar, "A study on the effects of high temperature on mechanical properties of fiber reinforced cementitious composites," Composites Part B: Engineering, vol. 43, no. 5, pp. 2452-2463, 2012.

[42] H. Tanyildizi, "Effect of temperature, carbon fibers, and silica fume on the mechanical properties of lightweight concretes," New Carbon Materials, vol. 23, no. 4, pp. 339-344, 2008.

[43] J. Sharma, S. Chawla, and S. Dalhotra, "A research agenda on artificial neural network topologies \& data mining in neural network," International Journal of Data \& Network Security, vol. 1, pp. 41-47, 2013.

[44] Z. H. Duan, S. C. Kou, and C. S. Poon, "Prediction of compressive strength of recycled aggregate concrete using artificial neural networks," Construction and Building Materials, vol. 40, pp. 1200-1206, 2013.

[45] D. Hanbay, I. Turkoglu, and Y. Demir, "An expert system based on wavelet decomposition and neural network for modeling Chua's circuit," Expert Systems with Applications, vol. 34, no. 4, pp. 2278-2283, 2008.

[46] S. Haykin, Neural Networks, a Comprehensive Foundation, Prentice Hall, Upper Saddle River, NJ, USA, 1994.

[47] D. Hanbay, I. Turkoglu, and Y. Demir, "Prediction of wastewater treatment plant performance based on wavelet packet decomposition and neural networks," Expert Systems with Applications, vol. 34, no. 2, pp. 1038-1043, 2008.

[48] H. Erdem, "Prediction of the moment capacity of reinforced concrete slabs in fire using artificial neural networks," $A d$ vances in Engineering Software, vol. 41, no. 2, pp. 270-276, 2010.

[49] L. Bal and F. Buyle-Bodin, "Artificial neural network for predicting drying shrinkage of concrete," Construction and Building Materials, vol. 38, pp. 248-254, 2013.

[50] M. Jalal and A. A. Ramezanianpour, "Strength enhancement modeling of concrete cylinders confined with CFRP composites using artificial neural networks," Composites Part B: Engineering, vol. 43, no. 8, pp. 2990-3000, 2012.

[51] E. M. Golafshani, A. Rahai, M. H. Sebt, and H. Akbarpour, "Prediction of bond strength of spliced steel bars in concrete using artificial neural network and fuzzy logic," Construction and Building Materials, vol. 36, pp. 411-418, 2012.

[52] E. Deniz, "ANN-based MPPT algorithm for solar PMSM drive system fed by direct-connected PV array," Neural Computing and Applications, vol. 28, no. 10, pp. 3061-3072, 2017.

[53] O. Karahan, H. Tanyildizi, and C. D. Atis, "An artificial neural network approach for prediction of long-term strength properties of steel fiber reinforced concrete containing fly 
ash," Journal of Zhejiang University-Science A, vol. 9, no. 11, pp. 1514-1523, 2008.

[54] H. Tanyildizi, "Prediction of compressive strength of lightweight mortar exposed to sulfate attack," Computers and Concrete, vol. 19, no. 2, pp. 217-226, 2017.

[55] M. Sarıdemir, I. B. Topcu, F. Ozcan, and M. H. Severcan, "Prediction of long-term effects of GGBFS on compressive strength of concrete by artificial neural networks and fuzzy logic," Construction and Building Materials, vol. 23, no. 3, pp. 1279-1286, 2009.

[56] P. Yuvaraj, A. R. Murthy, N. R. Iyer, S. K. Sekar, and P. Samui, "Support vector regression based models to predict fracture characteristics of high strength and ultra high strength concrete beams," Engineering Fracture Mechanics, vol. 98, pp. 29-43, 2013.

[57] V. N. Vapnik, The Nature of Statistical Learning Theory, Springer-Verlag, New York, NY, USA, 1995.

[58] V. Kecman, Learning and Soft Computing: Support Vector Machines, Neural Network and Fuzzy Logic Models, MIT Press, Cambridge, MA, USA, London, England, 2001.

[59] T. M. Cover, "Geometrical and statistical properties of systems of linear inequalities with applications in pattern recognition," IEEE Transactions on Electronic Computers, vol. 14, no. 3, pp. 326-334, 1965.

[60] K. Yan and C. Shi, "Prediction of elastic modulus of normal and high strength concrete by support vector machine," Construction and Building Materials, vol. 24, no. 8, pp. 1479-1485, 2010. 


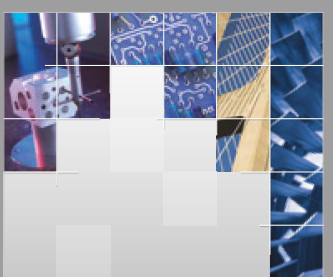

\section{Enfincering}
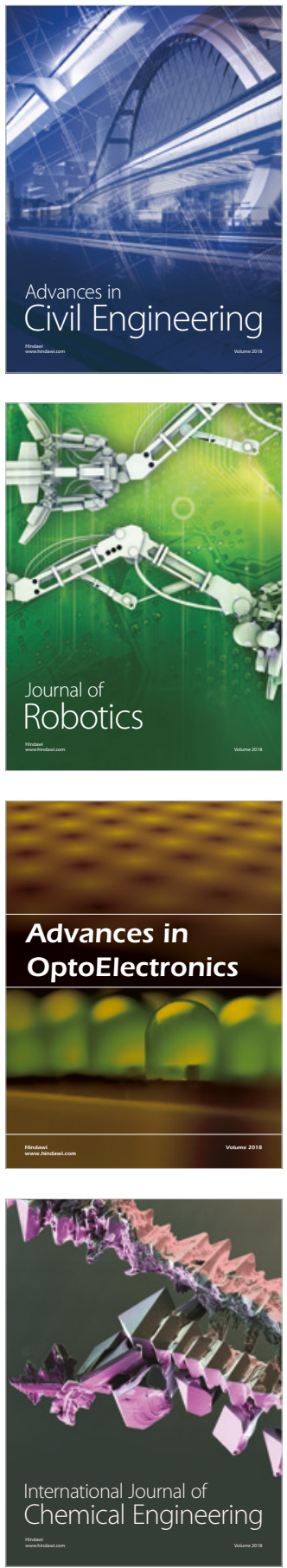

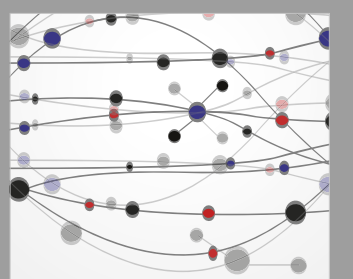

\section{Rotating \\ Machinery}

The Scientific World Journal

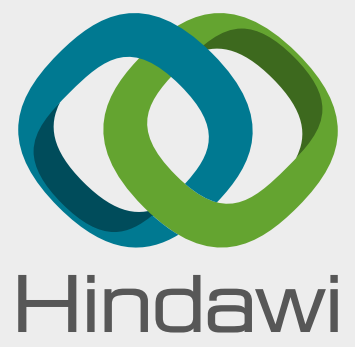

Submit your manuscripts at

www.hindawi.com
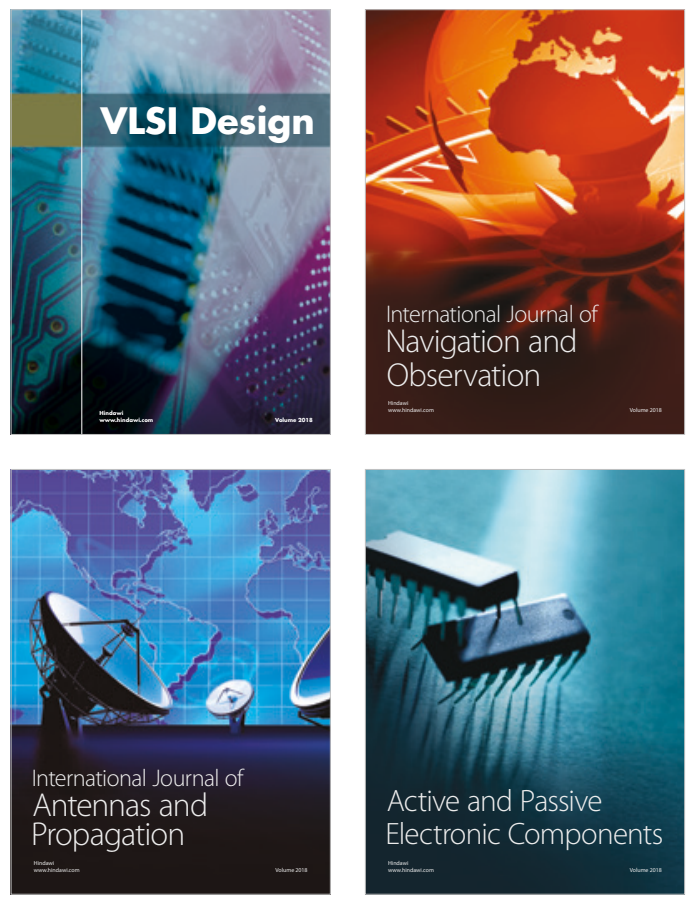
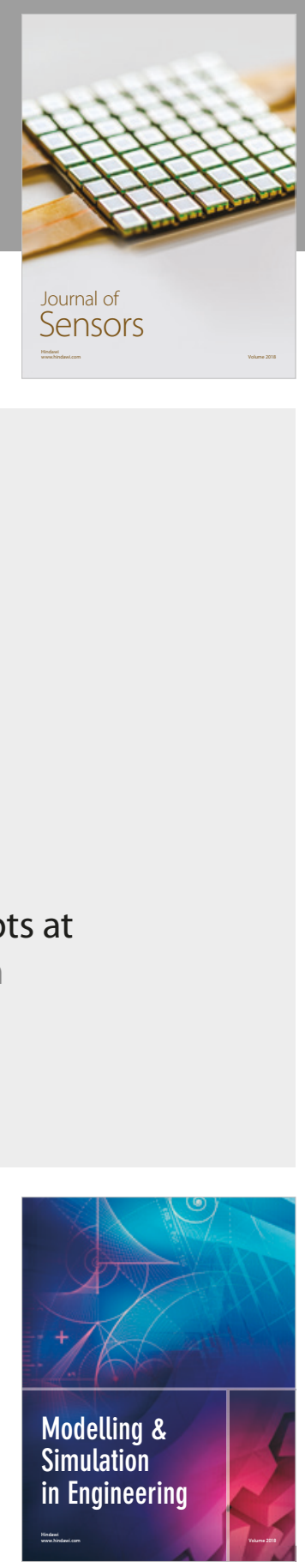

\section{Advances \\ Multimedia}
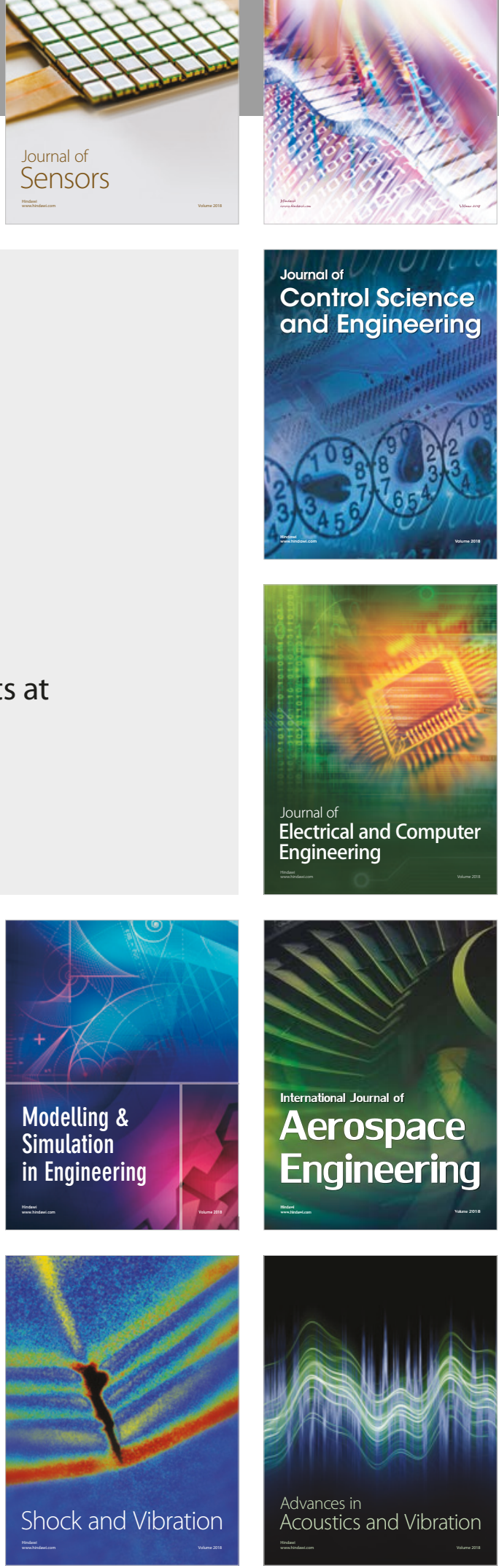